\title{
Prevention of diabetes in primary healthcare based on the health policy program for early detection and prevention of diabetes and its complications in working individuals in the Lubusz province
}

\author{
IWONA BONIKOWSKA ${ }^{1, B-E}$, JUSTYNA JASIK-PYZDROWSKA ${ }^{1, B, D-F}$, IWONA TOWPIK $^{2, A, D}$
}

\author{
${ }^{1}$ Faculty of Nursing, Department of Medicine and Health Sciences, University of Zielona Gora, Poland \\ ${ }^{2}$ Faculty of Internal Medicine, Department of Medicine and Health Sciences, University of Zielona Gora, Poland
}

A - Study Design, B - Data Collection, C - Statistical Analysis, D - Data Interpretation, E - Manuscript Preparation, F - Literature Search, G - Funds Collection

Summary Background. The term "diabetes" refers not only to a single disease state, but also to a group of many chronic metabolic disorders. Lack of symptoms leads to late diagnosis and treatment of diabetes. Early detection of abnormalities and pre-diabetic status becomes a priority.

Objectives. The aim of this work is to assess the prevalence of carbohydrate metabolism disorders amongst people capable of professional activity in the Lubuskie province.

Materials and methods. The research was carried out as part of the Health Policy Program for the early detection and prevention of diabetes and its complications in persons capable of professional activity in the Lubuskie Voivodeship, from January to April 2018, in the basic health center in Zielona Gora. Participants were selected using the recommended FINDRISK questionnaire (IDF) to perform the OGTT in a certified analytical laboratory. Participants with pre-diabetes were included in the educational program (third stage). The paper presents the analysis of preliminary data obtained in the first period of the program at the first and the second stage. The research covered 474 people aged 16 to 90 years.

Results. In that $73.42 \%$ (348) of participants were classed as having high or very high risk of developing diabetes, 59\% (205) completed the OGTT, in which 90 (43.9\%) participant had a normal result, 16 (7.8\%) participant had values in $120 \mathrm{~min}$. below $70 \mathrm{mg} / \mathrm{dl}, 19$ (9.27\%) had diabetes, and $80(39.03 \%)$ were found to be in a pre-diabetic state.

Conclusions. The scale of the diagnosed condition of pre-diabetes among the inhabitants of the Lubuskie region confirms the general regional, national and global tendency that the problem of diabetes is constantly and dynamically increasing.

Key words: primary health care, diabetes mellitus, pre-diabetic state, primary prevention.

Bonikowska I, Jasik-Pyzdrowska J, Towpik I. Prevention of diabetes in primary healthcare based on the health policy program for early detection and prevention of diabetes and its complications in working individuals in the Lubusz province. Fam Med Prim Care Rev 2018; 20(4): 313-319, doi: https://doi.org/10.5114/fmpcr.2018.79340.

\section{Background}

Diabetes has grown into a pandemic and has become one of the most serious health issues in the world. The World Health Organization's (WHO) Global Report on Diabetes, published in 2016, estimated the number of people living with diabetes in 2014 to be 422 million [1]. By contrast, in 1980, the number of diabetics was 108 million; and therefore within the space of 34 years, there has been a nearly four-fold increase in cases. Forecasts by the International Diabetes Federation (IDF) predict that the number of people living with diabetes globally in 2045 will be 629 million, representing a 48\% increase from 2017, when the number of people suffering from diabetes was 425 million [2]. Within the WHO's European Region, the number of diabetics is estimated to be 64 million. According to information from the Polish country profile of the WHO report, the prevalence of diabetes in the country is $9.5 \%$, while that of obesity (a risk factor of the disease) is 64\%. In 2017, the Public Health Committee of the Polish Academy of the Sciences (Polska Akademia Nauk, PAN) presented the results of epidemiological research on the incidence of diabetes that reflected the actual prevalence of the disease according to data from the National Health Fund (Narodowy Fundusz Zdrowia, NFZ), the RECEPTOmetr Sequence
TM program and from the NATPOL 2011 study [3-5]. According to the aforementioned data, the total number of people living in with diabetes in Poland in 2013 was 2.73 million, making up $7 \%$ of the total Polish population, including $26 \%$ of undiagnosed cases $[3,4]$. The number of people with pre-diabetes was two times higher, and the NATPOL study found impaired fasting glycaemia (IFG) in $15.6 \%$ of the population [5].

In 2015, diabetes was diagnosed in another 10464 people from Lubuskie, including the number of cases of type 2 diabetes (9 121), which is $87 \%$ of all diagnoses of various forms of the disease diagnosed for the first time this year. The majority of people diagnosed with type 2 diabetes, amounting to 9098 cases $(99.7 \%)$, were people at the age of readiness for professional activity, currently defined as persons aged 16 and above. The number of patients diagnosed with ICD-10 for diabetes treated in Lubuskie in 2017 was 56 821. The estimated number of people with pre-diabetes in the population above 15 years of age is more than twice the number of people with diabetes, which is $2 \times 56821$, thus more than 113642 people [6]. Based on clinical research [7], it is estimated that on average, $70-90 \%$ of people with pre-diabetic status develop diabetes at different times, and the average conversion rate is $11 \%$ per year [8]. 
One of the priorities of Primary Healthcare is prevention in its broader sense. The prevention of cardiovascular complications is becoming one of the challenges of modern family medicine. A diagnosis of diabetes is usually preceded by a period of impaired glucose metabolism and/or the occurrence of other risk factors. The state of impaired glucose metabolism is referred to as pre-diabetes, and it includes impaired fasting glucose (IFG) and impaired glucose tolerance (IGT) [9]. Individuals with IFG have a five times greater annual risk of developing type 2 diabetes, while those with IGT have a six times higher risk compared to individuals with normal glucose metabolism [10]. The most important test for early detection of metabolic impairments, and especially pre-diabetes, is the oral glucose tolerance test (OGTT) [11].

Low detectability of people with pre-diabetes in Lubuskie justifies taking all possible actions that can change this situation. In 2017, the Lubuskie province introduced for the first time the "Health policy program for early detection and prevention of diabetes and its complications in working individuals in the Lubuskie province" [12]. Primary healthcare centers providing healthcare services within the Lubuskie province were invited to be involved in the implementation of the program in Zielona Gora.

\section{Objectives}

The aim of this work is to assess the prevalence of carbohydrate metabolism disorders amongst increasingly younger and working residents capable of professional activity in the Lubuskie province.

\section{Material and methods}

\section{Study design}

A fundamental aspect of the program is conducting screening tests (first stage) for diabetes in the population of working individuals with the highest risk of developing diabetes.

\section{Study setting}

The study was conducted in the period January-April 2018. This was a survey involving Polish primary care patients in Zielona Gora. The program is planned to run until the end of 2019 and will include 1800 respondents. The preliminary data from the survey conducted between January and April 2018 is presented below.

\section{Participants}

Criterion of inclusion in the first stage: people over 16, who have not been treated for diabetes so far and have not been screened for diabetes in the last year. Participants were invited to participate in the program through the conducting of an information campaign about the program in local media (regional $\mathrm{TV}$, radio stations, press), on social networks and in medical facilities. This included 474 people, aged $16-90$, and the selection of the study group was random. The participants -348 people, were selected using the IDF-recommended FINDRISK questionnaire, designed by the authors of the Finnish National Diabetes Prevention Program $[13,14]$. This is a simple tool assessing the most significant risk factors for type 2 diabetes. Participants scoring $\geq 15$ points in the FINDRISK questionnaire qualified for the OGTT. The OGTT was conducted in a certified analytical laboratory using the fluoride plasma method. The pre-diabetes group was included in the third stage. The criterion of inclusion in the third stage was the assessment of carbohydrate metabolism disorders based on OGTT - IGT qualification (fasting 100-125 mg/ /dl), IFG (in 120 mins > 140-199 mg/dl), IGT and IFG; exclusion criterion: diagnosis of type 2 diabetes, diagnosis of hyperglycemia during pregnancy, an OGTT done in the last year, presence of psychotic symptoms, dementia, addiction to alcohol, drugs, cardio-vascular incident (myocardial infarction, stroke) during the last 6 months. The third stage includes the implementation of diabetes prevention principles in the group of people with pre-diabetes diagnosed based on the use of only behavioral changes. The subjects fill in the questionnaires assessing the way of eating - the nutritional index questionnaire "Health-promoting index" (pHDI-8) and its components, the "Index of unhealthy diet" (pHDI) and its components, assessments on food and nutrition. Survey evaluating activity physical activity was assessed using the International Physical Activity questionnaire. Participants were informed about the aims of the study and of the results of their blood test (verbally and in writing) and gave their written consent for participating in the study. After a year of implementing the program, each participant will complete another glucose tolerance test, and anthropometric parameters and RR and will be measured to assess the effectiveness of the preventative measures implemented.

\section{Variables}

The assessment of the increase in the identification of people with pre-diabetes will be based on a comparison of the number of people with pre-diabetes (R73 in ICD-10) detected over 1 year before the program and comparison with the number of people detected during the first year of the program. The assessment of the reduction in the number of people unaware of diabetes (undiagnosed) will be done by determining the number of new cases of type 2 diabetes, detected during screening during the first year of the program and comparing it with the number of new cases detected within 1 year preceding the program implementation at a primary healthcare center. The measure of obtaining the main goal of reducing the number of new cases among people at high risk participating in the program will be to determine the percentage of program participants who will be identified at the end of the study and to compare this with the average empirical percentage that can be achieved within 1 year.

\section{Bias}

The program was reviewed positively by the Agency for Health Technology Assessment and Tariff Systems (no. 8/2017 from January $\left.16^{\text {th }}, 2017\right)$.

\section{Statistical methods}

Statistical analysis was conducted using the STATISTICA v.13 PL package and the EXCEL spreadsheet program, and the significance threshold was set at $p<0.05$.

\section{Results}

\section{Participants and descriptive data}

The first stage of the study was completed by 474 respondents aged between $16-90$ years (mean $=56$ ). The majority of the group was made up of females (68.14\%), while males made up $31.85 \%$. Inhabitants of cities made up the majority $-84.6 \%$, those having an upper secondary education $-48.94 \%$, and professionally active $-54.43 \%$ (Table 1 ). 


\begin{tabular}{|c|c|c|c|c|}
\hline \multicolumn{2}{|c|}{ Socio-demographic data } & \multicolumn{2}{|c|}{ Patients } & \multirow{2}{*}{$\begin{array}{l}\begin{array}{l}\text { Statistical } \\
\text { significance }\end{array} \\
p<0.05\end{array}$} \\
\hline & & $n=474$ & $\%$ & \\
\hline \multirow[t]{2}{*}{ Gender } & female & 323 & 68 & \multirow{18}{*}{$p<0.001$} \\
\hline & male & 151 & 32 & \\
\hline \multirow[t]{5}{*}{ Age } & from 16 to 30 years & 40 & 8.44 & \\
\hline & from 31 to 40 years & 57 & 12.03 & \\
\hline & from 41 to 50 years & 66 & 13.92 & \\
\hline & from 51 to 60 years & 114 & 24.05 & \\
\hline & over 61 years & 197 & 41.56 & \\
\hline \multirow[t]{4}{*}{ Education } & primary & 29 & 6.12 & \\
\hline & vocational & 81 & 17.09 & \\
\hline & upper secondary & 232 & 48.94 & \\
\hline & higher & 132 & 27.85 & \\
\hline \multirow{2}{*}{$\begin{array}{l}\text { Place of } \\
\text { residence }\end{array}$} & rural & 73 & 15.4 & \\
\hline & city & 401 & 84.6 & \\
\hline \multirow{5}{*}{$\begin{array}{l}\text { Employ- } \\
\text { ment } \\
\text { status }\end{array}$} & unemployed & 2 & 0.42 & \\
\hline & working & 258 & 54.43 & \\
\hline & retired & 183 & 38.61 & \\
\hline & pensioner & 22 & 4.64 & \\
\hline & student & 9 & 1.9 & \\
\hline
\end{tabular}

Source: own design.

The first stage of the program was to assess the risk of developing type 2 diabetes within the next 10 years using the FINDRISK questionnaire. A clear majority, i.e. every third female respondent and every fifth male participant, fell into the high-risk group for developing diabetes (Table 2).

Based on scoring $\geq 15$ points on the FINDRISK questionnaire, 348 individuals qualified for taking the OGTT. The majority of this group was made up of females, $65.52 \%$, while males made up $34.48 \%$. The respondents were aged $18-90$ years, with a mean age of 58 years, SD 13.97. The majority were living in a city $-85 \%$, had an upper secondary education $-50 \%$, were working $-51 \%$; the remainder were retired $-43 \%$, pensioners $5 \%$, and students $-1 \%$.

\begin{tabular}{|c|c|c|c|c|c|}
\hline \multirow{2}{*}{\multicolumn{2}{|c|}{$\begin{array}{l}\text { Number of } \\
\text { points scored in } \\
\text { FINDRISK }\end{array}$}} & \multirow{4}{*}{\begin{tabular}{|l|}
$\begin{array}{l}\text { Age } \\
\text { range in } \\
\text { years }\end{array}$ \\
$16-83$ \\
$M: 43$
\end{tabular}} & \multicolumn{2}{|l|}{ Patients } & \multirow{2}{*}{\begin{tabular}{|l|}
$\begin{array}{l}\text { Statis- } \\
\text { tical } \\
\text { signifi- } \\
\text { cance }\end{array}$ \\
$p<0.05$ \\
\end{tabular}} \\
\hline & & & $n=474$ & $\%$ & \\
\hline \multirow[t]{2}{*}{$<7-$ low } & $\mathrm{F}$ & & 43 & 9.07 & \multirow{10}{*}{$p<0.001$} \\
\hline & $M$ & & 14 & 2.95 & \\
\hline \multirow{2}{*}{$\begin{array}{l}7-11 \\
- \text { medium } \\
\text { low }\end{array}$} & $\mathrm{F}$ & \multirow{2}{*}{$\begin{array}{l}22-81 \\
\text { M: } 52\end{array}$} & 40 & 8.44 & \\
\hline & $M$ & & 10 & 2.11 & \\
\hline \multirow{2}{*}{$\begin{array}{l}12-14 \\
- \text { medium }\end{array}$} & $\mathrm{F}$ & \multirow{2}{*}{$\begin{array}{l}25-72 \\
\text { M: } 49\end{array}$} & 12 & 2.53 & \\
\hline & $M$ & & 7 & 1.48 & \\
\hline \multirow{2}{*}{$\begin{array}{l}15-20 \\
- \text { high }\end{array}$} & $\mathrm{F}$ & \multirow{2}{*}{$\begin{array}{l}18-90 \\
M: 57\end{array}$} & 178 & 37.55 & \\
\hline & $M$ & & 89 & 18.78 & \\
\hline \multirow{2}{*}{$\begin{array}{l}>20 \\
- \text { very high }\end{array}$} & $\mathrm{F}$ & \multirow{2}{*}{$\begin{array}{l}37-82 \\
\text { M: } 61\end{array}$} & 50 & 10.55 & \\
\hline & $M$ & & 31 & 6.54 & \\
\hline
\end{tabular}

Source: own design.

\section{Main results}

In the group with a high risk of developing diabetes, the majority of respondents were in the 52-60 year old age bracket, while those with a very high risk were mainly in the 61-70 age bracket (Table 3).

In the second stage of the study, a fasting glucose test was completed by 205 individuals (Fig. 2), while the 120-minute OGTT was completed by 188 individuals due to poor tolerance of the orally administered $75 \mathrm{~g}$ glucose solution.

OGTT data was analyzed for participants with a high or very high risk of developing diabetes. In this group, 90 individuals (43.9\%) had a normal result, 16 (7.8) had hypoglycemia, $19(9.27 \%)$ had diabetes, and $80(39.03 \%)$ were pre-diabetic (Table 4).

\begin{tabular}{|c|c|c|c|c|c|c|c|c|c|c|c|c|}
\hline \multirow[t]{2}{*}{ Age } & \multicolumn{12}{|c|}{$\begin{array}{l}\text { Number of points scored in FINDRISK } \\
n=348\end{array}$} \\
\hline & 15 & 16 & 17 & 18 & 19 & 20 & 21 & 22 & 23 & 24 & 25 & 26 \\
\hline From 16 to 30 years & 1 & 1 & 6 & 2 & 0 & 0 & 0 & 0 & 0 & 0 & 0 & 0 \\
\hline From 31 to 40 years & 6 & 5 & 5 & 6 & 7 & 2 & 2 & 2 & 0 & 1 & 0 & 0 \\
\hline From 41 to 50 years & 8 & 5 & 10 & 5 & 9 & 3 & 0 & 6 & 0 & 1 & 0 & 0 \\
\hline From 51 to 60 years & 16 & 10 & 15 & 14 & 7 & 11 & 6 & 7 & 5 & 4 & 1 & 0 \\
\hline From 61 to 70 years & 3 & 7 & 7 & 13 & 17 & 10 & 6 & 4 & 10 & 6 & 5 & 2 \\
\hline Over 70 years & 5 & 3 & 6 & 24 & 6 & 10 & 6 & 1 & 2 & 3 & 4 & 0 \\
\hline Total = 348 & 39 & 31 & 49 & 64 & 46 & 36 & 20 & 20 & 17 & 15 & 9 & 2 \\
\hline
\end{tabular}

Source: own design.

Table 4. OGTT results in the FINDRISK questionnaire point brackets
\begin{tabular}{|l|l|l|l|l|l|l|l|l|}
\hline $\begin{array}{l}\text { Number of points } \\
\text { scored in FINDRISK }\end{array}$ & $n=348$ \\
\cline { 2 - 10 } & normal & $\%$ & pre-diabetes & $\%$ & diabetes & $\%$ & hypoglycemia & $\%$ \\
\hline $15-20-$ high & 72 & 35.12 & 55 & 26.83 & 12 & 5.85 & 13 & 6.34 \\
\hline$>20-$ very high & 18 & 8.78 & 25 & 12,2 & 7 & 3.42 & 3 & 1.46 \\
\hline Total & $\mathbf{9 0}$ & $\mathbf{4 3 . 9}$ & $\mathbf{8 0}$ & $\mathbf{3 9 . 0 3}$ & $\mathbf{1 9}$ & $\mathbf{9 . 2 7}$ & $\mathbf{1 6}$ & $\mathbf{7 . 8}$ \\
\hline
\end{tabular}

Source: own design. 


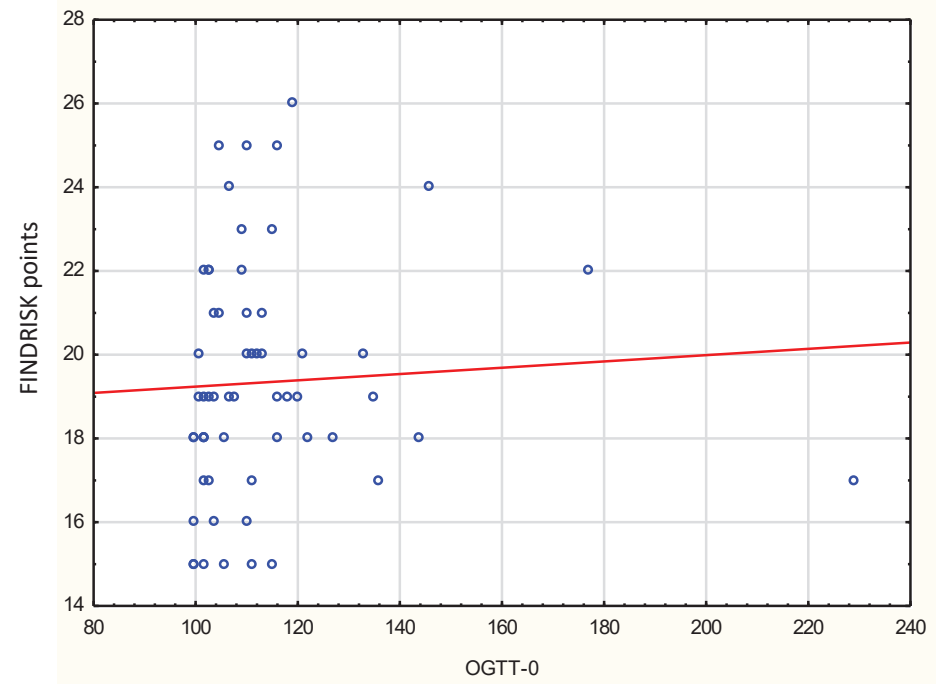

$n=58 ;$ mean $=114 ;$ SD $=20.71 ; \max =229 ; \min =100$

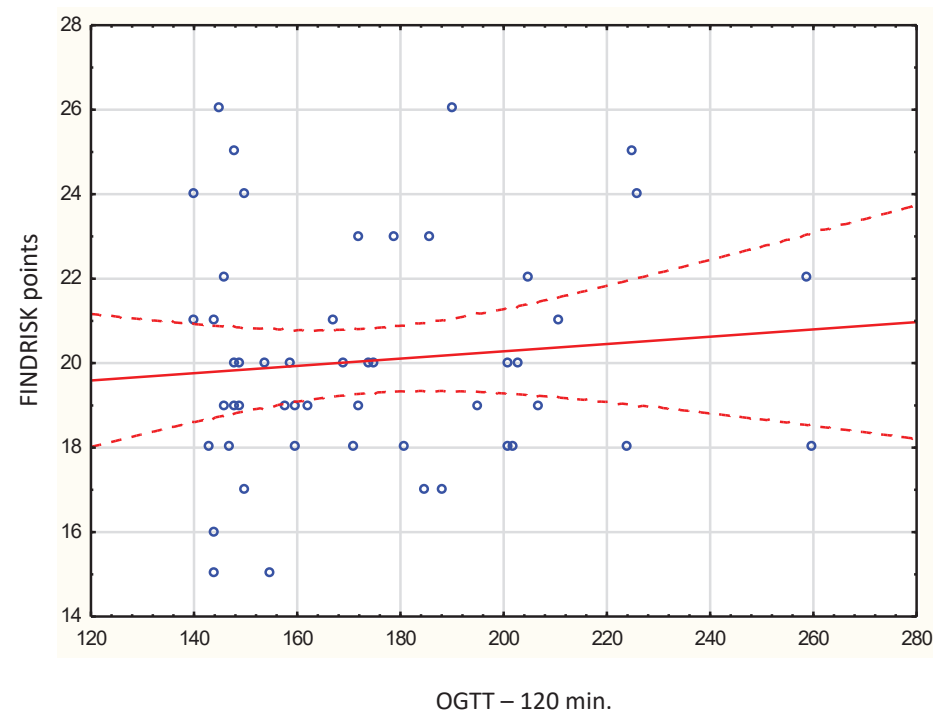

$n=50 ;$ mean $=174.34 ;$ St. Dev. $=30.49 ; \max =260 ; \min =140$

A detailed chart of the OGTT results in the FINDRISK questionnaire points brackets is illustrated in Figures 1 and 2 .

The results of the OGTT after fasting and after 120 minutes showed that 10 patient $(4.87 \%)$ who had normal fasting glycaemia had disturbances in carbohydrate metabolism (Table 5).

The risk of pre-diabetes increases with age, and in the younger age groups, IFG or IGT occurs, whereas with age, the disorder is related to IFG and IGT (Table 6).

\begin{tabular}{|c|c|c|c|}
\hline Age in years & $\begin{array}{l}\text { FINDRISK } \\
\text { points }\end{array}$ & $\begin{array}{l}\text { OGTT - } 0 \\
\mathrm{~h} / \mathrm{mg} / \mathrm{dl}\end{array}$ & $\begin{array}{l}\text { OGTT - } 120 \mathrm{~min} . \\
\mathrm{mg} / \mathrm{dll}\end{array}$ \\
\hline 44 & 17 & 99 & 51 \\
\hline 31 & 18 & 88 & 58 \\
\hline 60 & 18 & 92 & 69 \\
\hline 39 & 18 & 93 & 66 \\
\hline 72 & 18 & 99 & 181 \\
\hline 73 & 18 & 95 & 143 \\
\hline 82 & 19 & 98 & 148 \\
\hline 66 & 20 & 87 & 201 \\
\hline 48 & 22 & 94 & 146 \\
\hline 55 & 24 & 94 & 57 \\
\hline
\end{tabular}

Source: own design.
Figure 1. Fasting OGTT result $>100 \mathrm{mg} / \mathrm{dl}$ Source: own design.

Figure 2. Fasting OGTT result at minute $120>140$ $\mathrm{mg} / \mathrm{dl}$

Source: own design.
Table 6. The threat of diabetes risk development, pre-diabetes state $(n=80)$ in the individual age groups

\begin{tabular}{|l|l|l|l|}
\hline Age in years & IFG $n=76$ & IGT $n=38$ & IFG + IGT $n=38$ \\
\hline $16-30$ & $1(1.32 \%)$ & $1(2.63 \%)$ & $1(2.63 \%)$ \\
\hline $31-45$ & $7(9.29 \%)$ & $1(2.63 \%)$ & $1(2.63 \%)$ \\
\hline $46-60$ & $20(26.32 \%)$ & $11(28.95 \%)$ & $9(23.68 \%)$ \\
\hline $61-70$ & $30(39.47 \%)$ & $9(23.68 \%)$ & $17(44.74 \%)$ \\
\hline$>70$ & $18(23.68 \%)$ & $16(42.11 \%)$ & $10(26.32 \%)$ \\
\hline$p<0,05$ & $p=0.04$ & $p=0.00$ & $p=0.00$ \\
\hline
\end{tabular}

Source: own design.

Of note are the results in the youngest patients (below 45 years of age), where 33 individuals completed the OGTT, and over half (51\%) had an unfavorable result. In this group, 12 were found to be pre-diabetic, one had diabetes, and four had hypoglycemia. In the pre-diabetic group, 8 were diagnosed with IFG, 2 with both IFG and IGT, and 1 with IGT (Table 7). These results confirm the findings of many authors that the growth in incidence of diabetes is vast and involves increasingly younger patients.

The next stage of the program involved a medical examination and final qualification into the program. Exclusion criteria were the presence of psychotic symptoms, dementia, depen- 
dency on alcohol or drugs, or a cardiovascular incident in the last six months. 49 pre-diabetic patients took part in the next stage. Anthropometric measurements were taken - height, weight, BMI, waist-hip ratio (WHR) and two RR measurements, and the participants filled out a lifestyle questionnaire. Females made up $59 \%$ of this study group, with $37 \%$ being in the $51-60$ year age bracket, $55 \%$ had a normal-high BP, only $7 \%$ had a normal BMI, 31\% had first-degree overweight, 31\% had a normal WHR, and $61 \%$ assessed their physical activity to be in category I. Males made up $41 \%$ of the study group, where $61 \%$ were in the $51-70$ year age bracket, $45 \%$ had a normal-high $\mathrm{BP}$, half (50\%) had a normal BMI, while $45 \%$ were found to be overweight, $85 \%$ had a normal WHR, and $51 \%$ assessed their physical activity to be in category I. Based on these results and the data from the questionnaire, individual and group health education plans were devised.

\begin{tabular}{|c|c|c|c|}
\hline Age & FINDRISK points & OGTT - 0 & OGTT - $120 \mathrm{~min}$. \\
\hline 43 & 15 & 98 & 108 \\
\hline 32 & 15 & 92 & 105 \\
\hline 42 & 15 & 92 & 144 \\
\hline 41 & 15 & 82 & 73 \\
\hline 31 & 15 & 100 & 93 \\
\hline 43 & 16 & 83 & 50 \\
\hline 27 & 16 & 90 & 89 \\
\hline 36 & 16 & 93 & 44 \\
\hline 34 & 16 & 89 & 77 \\
\hline 39 & 16 & 104 & 93 \\
\hline 30 & 17 & 98 & 88 \\
\hline 27 & 17 & 103 & 150 \\
\hline 39 & 17 & 88 & 111 \\
\hline 40 & 17 & 113 & 83 \\
\hline 22 & 17 & 85 & 91 \\
\hline 44 & 17 & 99 & 51 \\
\hline 41 & 17 & 83 & 124 \\
\hline 39 & 18 & 93 & 66 \\
\hline 38 & 18 & 90 & 0 \\
\hline 30 & 18 & 100 & 94 \\
\hline 34 & 18 & 106 & 126 \\
\hline 31 & 18 & 88 & 58 \\
\hline 40 & 19 & 101 & 160 \\
\hline 43 & 19 & 100 & 116 \\
\hline 43 & 19 & 101 & 115 \\
\hline 41 & 19 & 103 & 91 \\
\hline 37 & 19 & 83 & 83 \\
\hline 37 & 19 & 99 & 88 \\
\hline 33 & 20 & 83 & 88 \\
\hline 44 & 22 & 177 & 0 \\
\hline 38 & 22 & 85 & 99 \\
\hline 41 & 22 & 109 & 105 \\
\hline 40 & 24 & 94 & 0 \\
\hline \multicolumn{4}{|c|}{$d=0.15588 ; p<0.05$} \\
\hline
\end{tabular}

Source: own design.

\section{Discussion}

Diabetes is becoming a significant public health issue, initiating a range of international, national, regional and local initiatives aiming to improve the situation for affected individuals and preventing the progression of the epidemic. The first global intervention initiative was the Declaration of St Vincent, inspired by the WHO and IDF in 1989, which delineated the progression of diabetes care [15]. However, a breakthrough in the global problem of diabetes was reached by the European Parliament declaration of 16.04.2006 and the UN resolution from 20.12.2006 [16], which recognized diabetes as the first non-contagious disease epidemic posing a global threat [13]. Since then, the European Parliament, IDF and WHO all call for prioritizing the prevention of diabetes in healthcare strategies and developing national plans for fighting diabetes [14]. In Poland, the first program for the prevention and treatment of diabetes was adopted in May 2006, and it began to be implemented in the form of pilot projects up to 2008 [18]. In 2010, Module II of the National Program for Tackling "Civilization Diseases" contained a Program for the Prevention and Treatment of Diabetes in Poland for the years 2010-2011 [19, 20]. In 2012, the National Program for Prophylaxis and Education on Diabetes was announced for 2012 [17]. As a result of regional initiatives, a few local preventative programs were conducted in individual provinces, districts and large metropolitan areas. Around $40 \%$ of patients with risk factors for type 2 diabetes present with dysfunctions in carbohydrate metabolism. This study shows that the problem of diabetes is growing and shows a increase of this problem in the youngest age groups. The studies also identify individuals who will have an increased risk of diabetes with age, and most of the patients studied will go on to develop diabetes. Diabetes Prevention Programmed (DPP) studies show that a change in lifestyle habits (diet, physical activity, reduced body weight) will decrease the risk of developing type 2 diabetes by $58 \%$ [12]. Similar results were obtained in the Finnish Diabetes Prevention Study (DPS) [13]. In summary, it can be said that in the majority of cases, type 2 diabetes can be avoided, but the findings of large clinical studies must be put into practice, i.e. into arduous, intensive and individualized therapeutic education, especially at primary healthcare centers.

A large difficulty associated with pre-diabetes is the lack of exact data on the scale of the issue. Pre-diabetes is not treated systematically, and when it is identified, there are no procedures about active non-pharmacological treatments base on behavioral changes. The program described here, which is an initiative outside NFZ funding, provides this option, but it is an incidental action. Complex and systematic action is needed that can and should be implemented in primary healthcare centers.

Based on the available data, there is a dynamically progressive increase in the incidence of diabetes in Lubuskie. In 2009, the number of people treated for diabetes in this region according to Lubuski Provincial Department of the National Health Fund amounted to 44330 people, while in 2015 there were 56136 patients, which is $5.5 \%$ of the total population of the region. In the province of Lubuskie, there have been no projects to assess how many people with pre-diabetes develop diabetes when the principles of its prevention are not implemented. Gerstein, based on a meta-analysis of studies published over the years $1979-2004$, determined that this risk is $5-10 \%$ for one year [21]. Scientific research studies confirm the effectiveness of preventive activities [22]. The results obtained by many Polish authors indicate that almost half of the population of young healthy people show elevated values of insulin resistance indexes and are at risk of developing carbohydrate disorders [23]. This condition at a young age is largely associated with lifestyle and is the reason for the increasing incidence of type 2 diabetes among younger and younger people [24]. Similar results were observed among students, and the percentage of people showing carbohydrate disturbances or insulin resistance, found on the basis of HOMA-IR or Matsuda indices, is alarmingly high [25]. This study shows that the highest risk of developing diabetes occurs in people over 60 years of age. People from the age group 46-60 are also at risk. The Polish Diabetes Association 
recommends active detection of diabetes by conducting screening tests in all people aged 45 and over every 3 years, as well as in people with an increased risk of developing diabetes (obese, leading an inactive lifestyle with hypertension, burdened with the occurrence of diabetes in the family, etc.), regardless of age, every year. The occurrence of glucose intolerance is an important indicator of the risk of developing diabetes and allows people in this group to take preventive measures. The results of the studies by Kurczewska-Michalak and Kardas [25] assessing the knowledge of selected cancer prevention methods among Polish patients of outpatient practitioners emphasize the great role of prophylaxis. Malignant neoplasms, as one of the diseases of our civilization, have become the largest challenge for world medicine in recent years. Therefore, effective prevention is of the utmost importance [23]. Thus, civilization diseases such as diabetes, cancer or cardiovascular diseases can be effectively treated, provided that effective methods of early detection and prevention are used. However, patient involvement is aprerequisite for the effectiveness of the programme.

The diagnosis of pre-diabetes, which is often reversible, may be very useful in everyday medical practice, as it will allow one to have an influence on the risk factors.

\section{Limitations of the study}

The limitations of this study are associated with:

1) limited knowledge about coexisting diseases and medicines taken by patients;

2) no analysis of other biochemical tests other than OGTT for inclusion or exclusion from the program.

\section{Conclusions}

1. The scale of the diagnosed state of pre-diabetes among the residents of the Lubuskie province confirms the general regional, national and global tendency that the problem of diabetes is constantly and dynamically increasing.

2. The disturbances in carbohydrate metabolism increasingly affect younger patients.

Source of funding: This work was funded by the authors' own resources.

Conflicts of interest: The authors declare no conflicts of interest.

\section{References}

1. World Health Organization. Global Report on Diabetes 2016. Geneva: WHO; 2016.

2. International Diabetes Federation. IDF Diabetes Atlas. (th $^{\text {th }}$ ed. Brussels: International Diabetes Federation; 2017 [cited 14.04.2018]. Available from URL: http://www.diabetesatlas.org/resources/2017-atlas.html.

3. Rutkowski M. Bandosz P, Czupryniak L, et al. Prevalence of diabetes and impaired fasting glucose in Poland - the NATPOL 2011 Study. Diabet Med 2014; 31(12): 1568-1571.

4. Cukrzyca w Polsce - pierwsze kompletne i wiarygodne opracowanie. Analizy Komitetu Zdrowia Publicznego PAN [cited 14.04.2018]. Available from URL: http://www.instytutpwn.pl/cukrzyca-w-polsce-analiza-komitetu-zdrowia-publicznego-pan/ (in Polish).

5. Zdrojewski T, Rutkowski M, Bandosz P, et al. Prevalence and control of cardiovascular risk factors in Poland. Assumptions and objectives of the NATPOL 2011 Survey. Kardiol Pol 2013; 71(4): 381-392.

6. Lubuski Oddział Wojewódzki NFZ. Załącznik nr 1 do pisma znak: WSOZ-II.0123.28.2018 (unpublished data) (in Polish).

7. Tabák AG, Herden C, Rathmann W, et al. Prediabetes: a high-risk state for developing diabetes. Lancet 2012(16); 379(9833): $2279-2290$.

8. Knowler WC, Fowler SE, Hamman RF, et al. 10-year follow-up of diabetes incidence and weight loss in the Diabetes Prevention Program Outcomes Study. Lancet 2009; 374(9702): 1677-1686.

9. Zalecenia kliniczne dotyczące postępowania u chorych na cukrzycę 2015. Stanowisko Polskiego Towarzystwa Diabetologicznego. Diabet Klin 2017; 3(supl. A): A6 (in Polish).

10. Santaguida PL, Balion C, Hunt D, et al. Diagnosis, prognosis and treatment of impaired glucose tolerance and impaired fasting glucose. Summary. In: AHRQ Evidence Report Summaries. Rockville: Agency for Healthcare Research and Quality; 2005.

11. Zasady postępowania w cukrzycy. Wytyczne Kolegium Lekarzy Rodzinnych w Polsce i Polskiego Towarzystwa Diabetologicznego 2011. Łódź: Wydawnictwo „AKTIS”; 2011: 14 (in Polish).

12. Program polityki zdrowotnej wczesnego wykrywania oraz zapobiegania rozwojowi cukrzycy i jej powikłaniom wśród osób w wieku aktywności zawodowej, zamieszkujących teren województwa lubuskiego. Departament Ochrony Zdrowia Urzędu Marszałkowskiego Województwa Lubuskiego w Zielonej Górze [cited 14.04.2018]. Available from URL: lubuskie.pl/uploads/pliki/Biuro_prasowe/ pliki2016/Zał (in Polish).

13. Sapilak BJ, Mastalerz-Migas A, Pokorna-Kałwak D. Wykorzystanie karty FINDRISC jako narzędzia oceny ryzyka rozwoju cukrzycy w populacji pacjentów z nadciśnieniem tętniczym w wieku podeszłym. Fam Med Prim Care Rev 2014; 16(2): 158-160 (in Polish).

14. Schwarz PE, Li J, Lindstrom J, et al. Tools for predicting the risk of type 2 diabetes in daily practice. Horm Metab Res 2009; 41(2): 86-97.

15. St Vincent Declaration 1989. Diabetes care and research in Europe: the St Vincent Declaration. Diabetic Med 1990; 7: 360.

16. Zawada-Targoni S. Ogłoszenie Rezolucji Zgromadzenia Ogólnego Organizacji Narodów Zjednoczonych w sprawie intensyfikacji walki z cukrzycą - zwycięstwo dla dobra chorych. Med Metabol 2007; 2: 8-9 (in Polish).

17. Zwalczanie epidemii cukrzycy w UE. P7 TA(2012)0082. Rezolucja Parlamentu Europejskiego z dnia 14 marca 2012 r. w sprawie działania w walce z epidemią cukrzycy w UE (2011/2911 (RSP)); Dz.U.UE.C.2013.251E.47 (2013/C 251 E/09) [cited 14.04.2018]. Available from URL: http://www.lex.pl/akt/- /akt/dz-u-ue-c-2013-251e-47 (in Polish).

18. Ministerstwo Zdrowia. Departament Polityki Zdrowotnej. Program polityki zdrowotnej. Program prewencji i leczenia cukrzycy w Polsce na lata 2006-2008 [cited 14.04.2018]. Available from URL: http://www2.mz.gov.pl/wwwmz/index (in Polish).

19. Ministerstwo Zdrowia. Narodowy Program zwalczania chorób cywilizacyjnych. Moduł II - Program Prewencji i Leczenia Cukrzycy w Polsce na lata 2010-2011 [cited 14.04.2018]. Available from URL: http://www2.mz.gov.pl/wwwfiles/ma_struktura/docs/program_10062010.pdf (in Polish).

20. Narodowy Program Przeciwdziałania Chorobom Cywilizacyjnym. Moduł II - Narodowy Program Profilaktyki i Edukacji Diabetologicznej na rok 2012 Ministerstwo Zdrowia. Programy Zdrowotne [cited 14.04.2018]. Available from URL: http://www2.mz.gov.pl/wwwfiles/ ma_struktura/docs/program_10062010.pdf (in Polish).

21. Gerstein HC, Santaguida P, Raina P, et al. Annual incidence and relative risk of diabetes in 22 people with various categories of dysglycemia: a systematic overview and meta-analysis of prospective studies. Diabetes Res Clin Pract 2007; 78(3): 305-312.

22. Madhuvrata P, Govinden G, Bustani R, et al. Prevention of gestational diabetes in pregnant women with risk factors for gestational diabetes: a systematic review and meta-analysis of randomised trials. Obstet Med 2015; 8(2): 68-85.

23. Witek J, Witek P, Pańkowska E. Insulinooporność u dzieci. Pediatric Endocrinol Diab Metabol 2011; 17(4): $206-213$ (in Polish). 
24. Wójtowicz-Chomicz K, Borzęcki A. Czy wśród studentów Uniwersytetu Medycznego w Lublinie występuje zjawisko otyłości? Fam Med Prim Care Rev 2011; 13(2): 251-253 (in Polish).

25. Kurczewska-Michalak M, Kardas P. The knowledge of selected cancer prevention methods among Polish outpatients. Fam Med Prim Care Rev 2017; 19(3): 235-238.

26. Płaczkowska S, Kokot I, Pawlik-Sobecka L, et al. Wskaźniki insulinooporności wśród studentów wrocławskich uczelni - doniesienie wstępne. Fam Med Prim Care Rev 2013; 15(3): 370-371 (in Polish).

Tables: 7

Figures: 2

References: 26

Received: 15.05.2018

Reviewed: 27.06.2018

Accepted: 15.07 .2018

Address for correspondence:

Iwona Bonikowska, MSc

Zakład Pielęgniarstwa

Wydział Lekarski i Nauk o Zdrowiu

Uniwersytet Zielonogórski

ul. Energetyków 2

65-001 Zielona Góra

Polska

Tel.: + 48602 698-252

E-mail: i.bonikowska@wlnz.uz.zgora.pl 